\title{
Response of Biology Students toward Online Learning in the Covid-19 Pandemic Era
}

\author{
*Masiah, Srinopita Primawati \\ Biology Education Department, Universitas Pendidikan Mandalika, Jl. Pemuda No. 59A Mataram \\ 83125 , Indonesia
}

*Corresponding Author e-mail: masiah@ikipmataram.ac.id

Received: May 2021; Revised: June 2021; Published: June 2021

\begin{abstract}
This study aimed to describe student responses toward online learning. The respondents in this study were students of the first semester of the Biology Education Department in academic year 2019/2020, totaling 33 people. The sample in this study used a convenience sampling technique. The data obtained were analyzed descriptively using Microsoft Excel. Research data shows that only 6 percent of students feel happy with online learning, because respondents think that they are more flexible about the time and place of learning. Meanwhile, 91 percent of students stated that they were not happy due to many factors such as being difficult to meet faceto-face with friends and lecturers, requiring a lot of money to buy internet quota and an unstable internet network. Referring to these results, it is very necessary to conduct an evaluation by lecturers and relevant policy makers to support the achievement of maximum learning objectives.
\end{abstract}

Keywords: student response; online learning; covid-19 pandemic

How to Cite: Masiah, M., \& Primawati, S. (2021). Response of Biology Students toward Online Learning in the Covid-19 Pandemic Era. Prisma Sains : Jurnal Pengkajian Ilmu dan Pembelajaran Matematika dan IPA IKIP Mataram, 9(1), 114-121. doi:https://doi.org/10.33394/j-ps.v9i1.3856

https://doi.org/10.33394/j-ps.v9i1.3856

Copyright $\odot$ 2021, Masiah \& Primawati This is an open-access article under the CC-BY License. (c) $($ )

\section{INTRODUCTION}

The COVID-19 pandemic has caused an unprecedented world health crisis. Social restrictions are one of the most important things to do to suppress its spread, including social restrictions at the level of education units, both schools and universities. Many countries have decided to temporarily close schools, colleges and all educational institutions in order to prevent the spread of the corona virus in educational units (UNESCO, 2020).

Indonesia is one of the countries that implements social restrictions in the education unit environment because the implementation of education policies must consider the health of teachers, students, and all school members (Kemendikbud, 2020). As a result of these social restrictions, the Minister of Education and Culture issued a circular dated March 24, 2020 regarding the implementation of education during this pandemic. The circular is in the form of a Learning from Home policy through online learning. The purpose of implementing Learning from Home (WFH) is to ensure the fulfillment of students' rights to obtain educational services during the Covid-19 emergency, protect education unit residents from the adverse effects of Covid-19, prevent the spread and transmission of Covid-19 in education units and ensure the fulfillment of psychosocial support for educators, students, and parents (Kemendikbud, 2021).

When asked to choose between online or offline learning, there will certainly be various answers, as revealed by Padli (2020) through his research results stating that the average student prefers to study face-to-face instead of learning online because of constraints on facilities, costs and class interaction. . Andiarna (2020) also explained that online learning affects academic stress during the covid-19 pandemic. Online learning needs to be supported 
by facilities and infrastructure, readiness and skills of lecturers so that academic stress on students can be avoided. However, different results were presented by Sa'diayah (2021), according to him online learning has a positive impact on the learning outcomes of vocational students in office technology lessons. When viewed from the subjects studied, it is actually very supportive for online learning.

Istiningsih (2015) stated that online learning will become a learning trend in the future. Significant differences between online and offline learning of course also make changes in learning (Arkorful \& Abaidoo, 2014). Successful online learning requires the reconstruction of roles and responsibilities not only from lecturers but also from students (Vonderwell, 2004). Several studies reveal the advantages of online learning, including time flexibility and ease of task collection (Astuti, 2019), students have control over their learning because they can exercise direct control over information sources and can access what they need related to learning (Arnesi, 2015). Online learning can increase independence for students (Waryanto, 2006). But on the other hand, there are also studies that reveal weaknesses such as the difficulty of socializing between students, and the intensity of meeting between students and lecturers which is very minimal and almost non-existent in one semester so that students find it more difficult to understand learning (Wardani, 2018). This shows that it is very important to understand the state of the diverse online learning environment.

The importance of students' perceptions of learning was in line with research by Fitriana, Utaya and Budijanto (2016) which stated that a good perception of learning was one of the requirements for the learning process to run well too. Students' perceptions of the lesson will affect the desire of students to participate in the learning and a positive perception of learning will facilitate the achievement of maximum goals in learning (Mashuri, 2017). Thus the importance of student perceptions in learning as one of the determinants of achieving learning objectives, this makes it interesting to study especially the response to basic biology courses. Perception is a mental representation or response that is built as a result of experience with online lectures (Muntazhimah, 2020). The purpose of this study was to describe student responses to the policy of learning from home, especially the response to lectures on basic biology courses.

\section{METHOD}

This research was a quantitative descriptive study to describe or describe student responses to online lectures in basic biology courses. Respondents in this study were selected using convenience sampling technique. Convenience sampling is sampling based on the availability of elements and the ease of obtaining them (Sugiarto, 2001). The COVID-19 pandemic that occurred was the main consideration in choosing this sampling technique because it was considered appropriate in terms of time and ease of obtaining data. That way, anyone who agrees to provide the required information can be used as a sample in this study if the respondent is suitable as a data source. Respondents in this study were students of the first semester of the biology study program for the 2019/2020 academic year, totaling 33 people.

The research data was obtained through a questionnaire containing open-ended questions that could explore and describe student responses to learning. Of course, the questionnaire was first validated through expert judgment and readability to students. This questionnaire was compiled and distributed online with the help of Google Forms. The data collection procedures carried out by the researchers were (1) determining the research subject and (2) providing a student response questionnaire regarding their response to the policy of learning from home or online learning. All of the research steps were carried out online through various applications and electronic media. The data obtained were analyzed descriptively using Microsoft Excel software. 


\section{RESULTS AND DISCUSSION}

The world of education globally has been hit hard during the COVID-19 pandemic, this is because it affects $87.6 \%$ of the total registered students in the world and sadly there are 1.53 billion students affected by dropping out of school (ECW, 2020). Indonesia is one of the countries that has also been affected by the Covid-19 pandemic. The online learning process that has been going on for more than a year has elicited a variety of responses from students, including students of the biology education study program at the Mandalika University of Education (UNDIKMA) Mataram.

COVID-19 is a rapidly and radically transformative challenge, for which there are no manuals to regulate or guide the course of learning (OECD, 2020). Without proper preparation and the need to act immediately, lecturers carry out lectures as much as possible. In line with this, students seem to be forced and forced to accept online learning. The process that was forced to be carried out even in these difficult conditions resulted in mixed responses from the students. As is known in the Basic Biology course, there are some lecture materials that are difficult to understand if the lecture is done virtual. In addition, in the basic biology course there is a practicum that should be carried out in the laboratory, but again this cannot be done face-to-face. Such conditions add to the inconvenience of students studying online. The following describes some of the student responses to the questions provided.

\section{Emotional Response}

Based on Figure 1, it shows that only $6 \%$ of students stated that they were happy with online lectures. Various reasons were put forward by students who were not happy with online lectures, ranging from not being able to directly carry out practicals to test theories to reasons not being able to meet lecturers and friends.

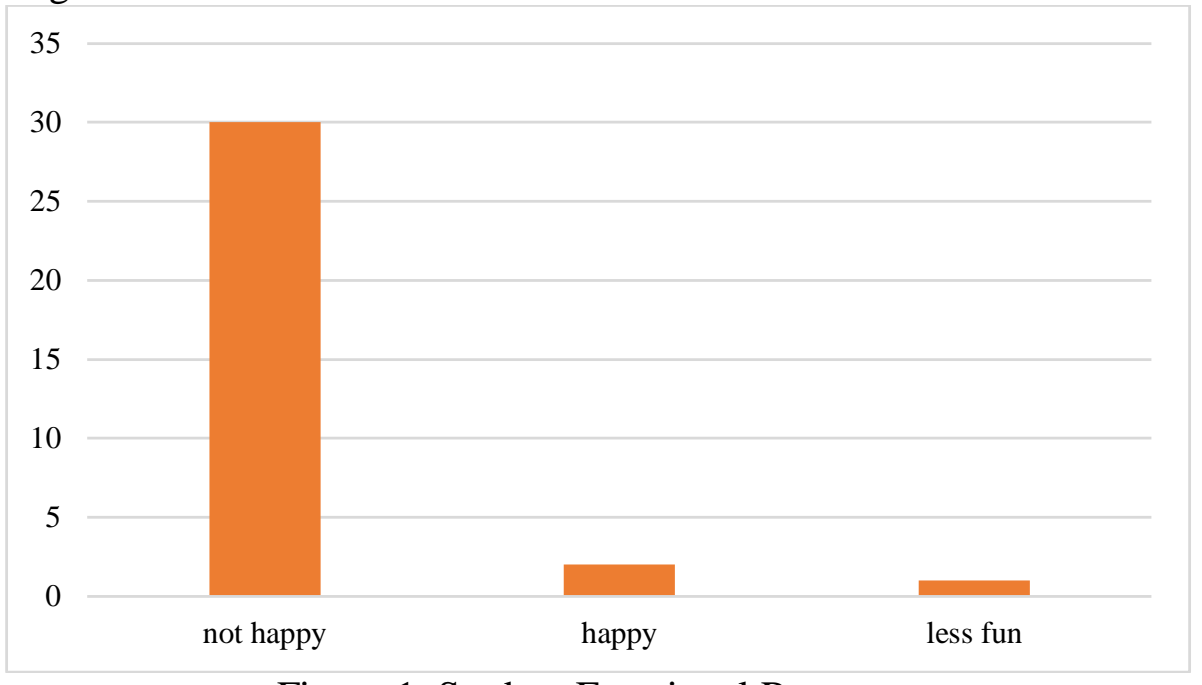

Figure 1. Student Emotional Response

The opinion of respondents who stated that they were happy was because studying or lectures could be done while working, and there were also those who had high awareness of the potential dangers of transmitting COVID-19 if they forced face-to-face lectures. Meanwhile, respondents who stated that they were not happy stated that they were resigned to the current reality. The figure of $91 \%$ of students who are not happy with online learning as shown in Diagram 1 above is certainly very sad, this response may arise from the boredom of students constantly studying in front of their cellphones or laptops. Seeing the high number of respondents' displeasure with online learning is certainly very concerning for all of us. However, this data is not much different from the data from the Indonesian Child Protection Commission (KPAI, 2020) which received 246 complaints related to online learning in April 2020 and the research results, namely $77.8 \%$ of students stated that they had difficulty undergoing online learning. The KPAI data is general online learning respondent data and the numbers may be different if the questions are more specifically directed at certain fields. The 
results of Muntazhimah's research (2020) also show that only 30 percent of students feel happy about learning online, and as many as 62 percent of students experience obstacles in doing it. Students who feel unhappy when undergoing learning, will certainly have an impact on their motivation in learning and when motivation in learning is not good, it will automatically have an impact on their learning outcomes, as expressed by Isnayni (2020), online learning makes students become difficult to understand the learning material and have an influence on the low learning achievement. Yunitasari (2020) also added that online learning during the COVID-19 pandemic greatly affected student interest in learning, students felt bored because they did not meet their friends and teachers directly. Meanwhile, from a psychological perspective, Hariyadi (2020) stated that online learning is less effective because there are so many obstacles that greatly affect student motivation, quality and learning outcomes.

\section{Cost}

Undikma students do not only come from the island of Lombok, but also come from almost all districts and cities throughout the Province of West Nusa Tenggara and also some from outside the region. The long distance between home and campus, requires students to choose a boarding house in Mataram City. Based on Figure 2 below, it shows that there are 18 respondents or about $55 \%$ of students agree that online learning can reduce boarding costs while they are studying.

About $33 \%$ of respondents stated that they did not agree, according to them the cost of boarding can be overcome, but the cost of buying internet quota has also increased and even exceeds the cost of renting a boarding house each month. This kind of obstacle should be overcome by the government by providing assistance equally to students, in practice currently the inequality of internet quota assistance is a complement to the obstacles faced by students.

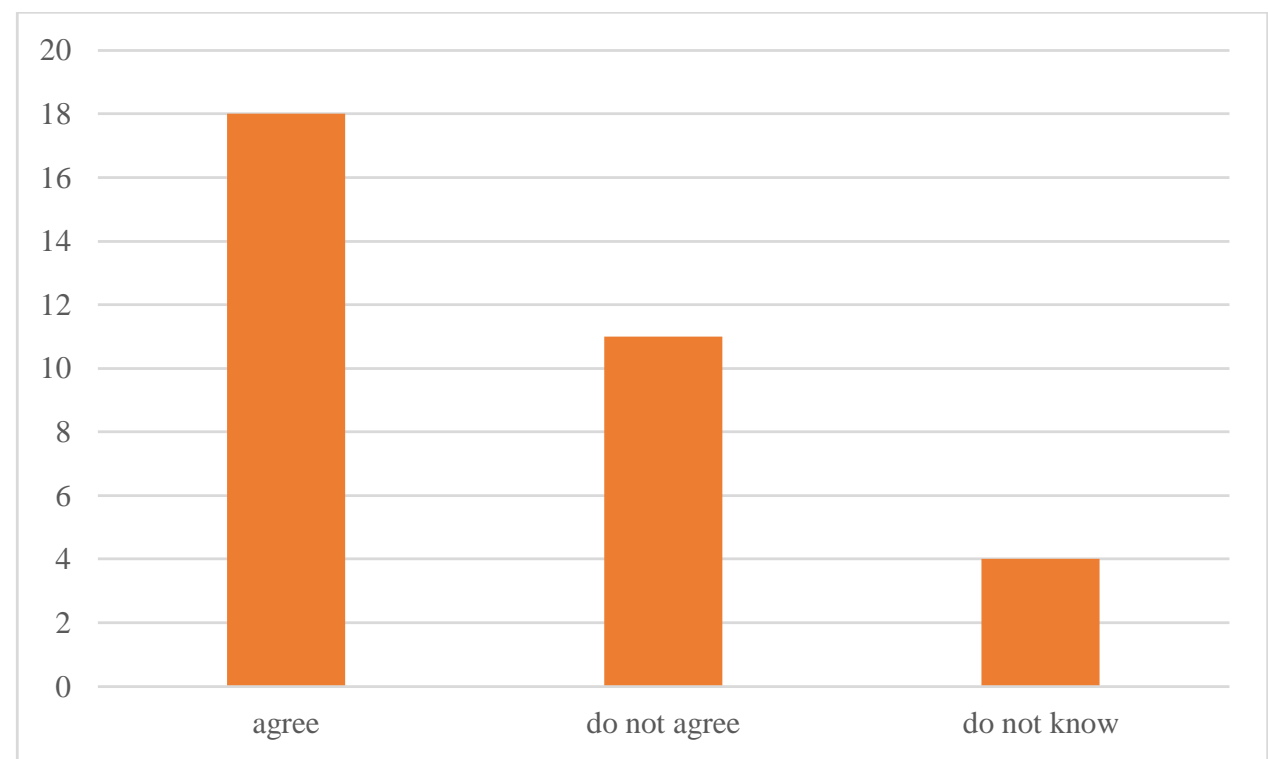

Figure 2. Student response to cost savings by studying online

The remaining $12 \%$ stated that they did not know, because they could not compare. Respondents who stated that on average were those who had never been in a boarding house because the distance from their home and campus was still supportive of going back and forth.

\section{Internet connection}

Another problem faced by students is related to the network. Having a smartphone and internet quota does not necessarily make students relieved to carry out online learning. Based on the data in Figure 3 below, it shows that there are 55\% of respondents whose areas are less stable with internet networks. Respondents who answered that their internet connection was 
less stable on average were respondents who were outside the city of Mataram, such as from Central Lombok, Gunungsari area which is located in a rather highland. This instability can be caused by the geographical location of their residence or also triggered by weather conditions and when there is a power outage from PLN, besides that the type of provider used by respondents can affect the internet network in their respective areas.

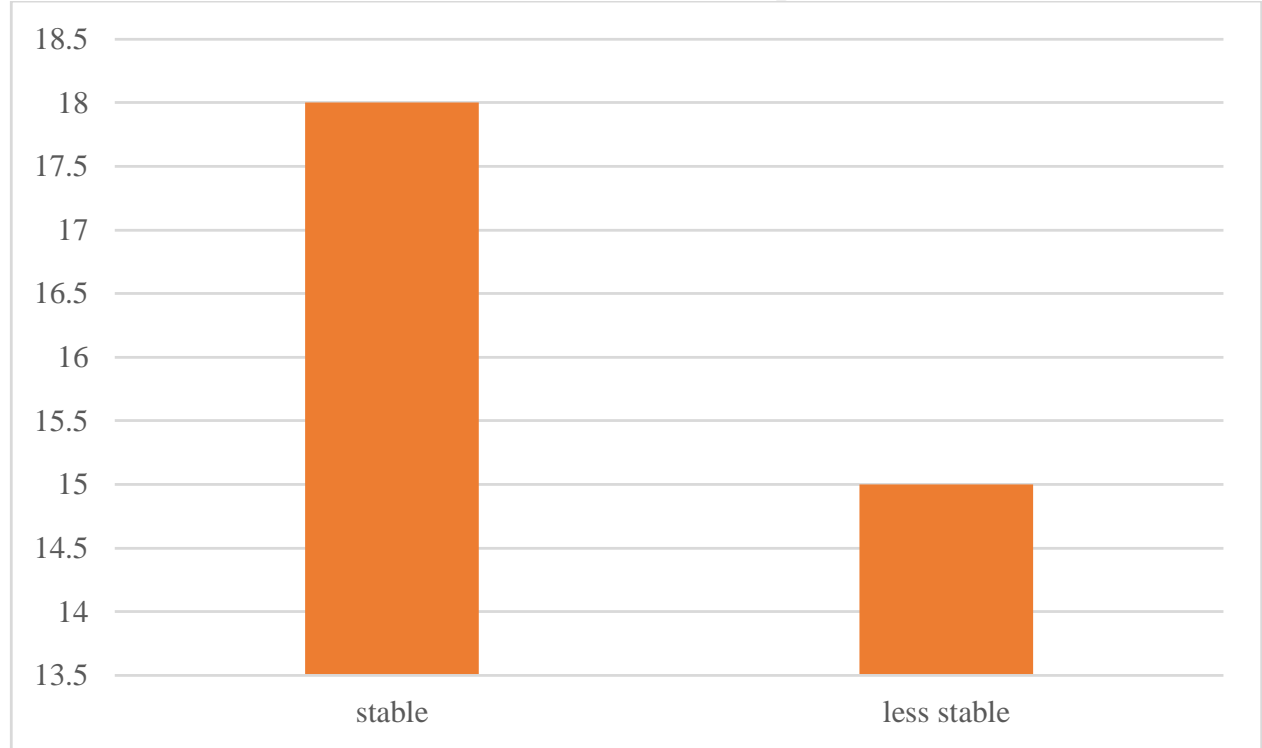

Figure 3. Student response to internet connection

Quoted from the kominfo.go.id page, since 2018, the government has been trying to make internet access even. With the development of supporting infrastructure so that there is no longer inequality in adequate internet access and this is targeted to be completed as a whole by 2022, the speed is five times from now. Students experience problems with unstable networks when online classes take place, such as difficulties in absorbing the material given by lecturers because of the lack of traceability of the explanations they hear when there are network constraints (Dzalila, 2020). This condition resulted in the material being delivered by the lecturer not being maximal, so the material being absorbed by the students was not maximal.

\section{Weaknesses and Strengthness}

The weakness of online learning that most respondents feel is the difficulty of meeting and interacting directly between friends and lecturers in one room. Another drawback is the cost of providing internet quota increases and the network is less stable. Other studies that explain the weaknesses of online learning such as this were also revealed by Wardani, Toenlioe \& Wedi (2018). In addition, according to respondents, they are less qualified in understanding and utilizing virtual media to support their learning, for example in terms of doing practicals in the laboratory, there is a virtual laboratory that can be used to support their learning. In line with this, Thahir, Roza \& Murni (2018) stated that lecturers and students still do not understand the importance of the existence of Website-Based Learning and its benefits to improve learning.

As for the advantages, as revealed by respondents, lectures become more flexible, can be done in the room while sitting, standing, even lying down or while eating. In addition, online lectures require students to be more technologically literate. The results of this study are also supported by the research of Sobron et al. (2019) which states that the creation of a learning community without being limited by space and time is also a positive impact of online learning. Rahman, Munawar and Berman (2014) also state that the use of online learning allows us to access and obtain explanations of text, graphics, images, photos, animations, audio and video in learning. 


\section{Hope if the Pandemic is not over}

In this section, respondents are asked to write down their expectations regarding the technical lectures they want if in the next semester the pandemic has not ended.

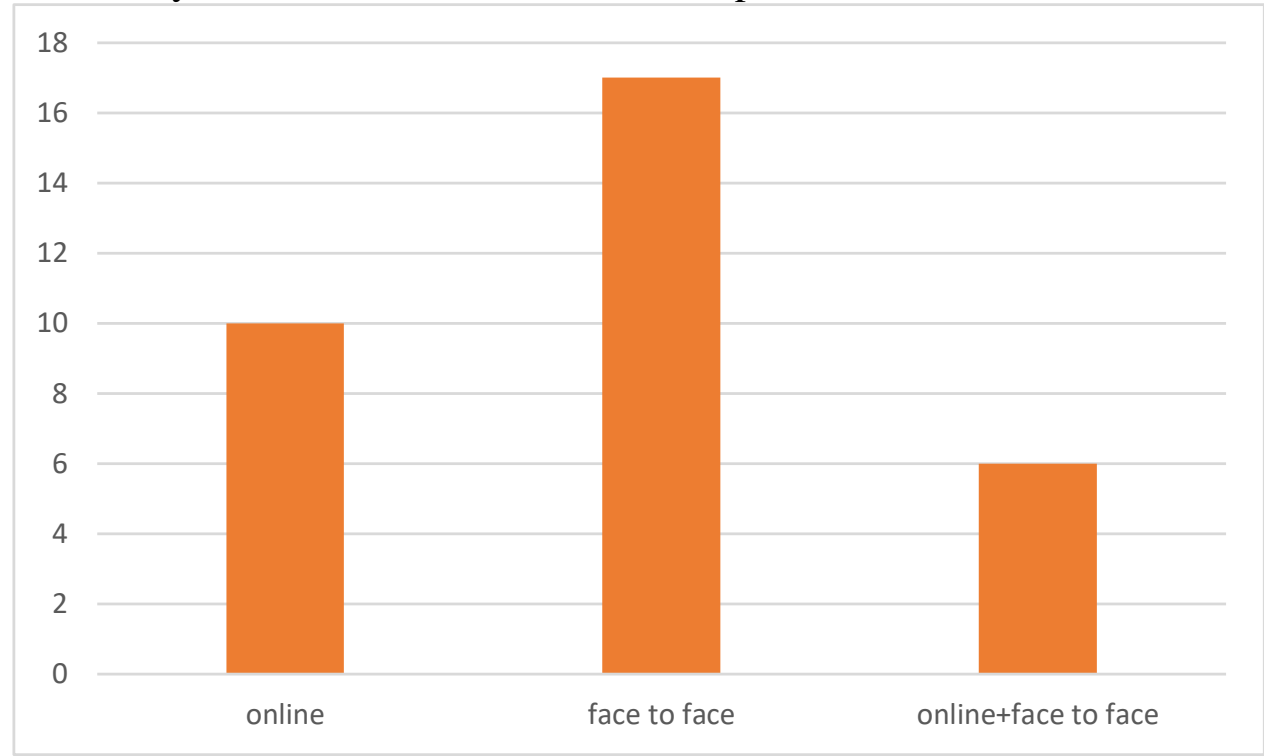

Figure 4. Student expectations

Referring to Figure 4 above, there are $52 \%$ of respondents who want face-to-face lectures even though they are still in a pandemic condition. Such hope arises from the boredom of respondents studying online which is far from direct socialization with friends and lecturers. Some respondents who wanted to learn face-to-face also emphasized that they should obey the health protocol, so even if the lecture was face-to-face, the health protocol had to be adhered to so that the transmission of the COVID-19 virus did not occur. Purwanto's research, et al (2020) states that the learning process during a pandemic felt by students is that they do not have adequate facilities and infrastructure to implement online learning, this triggers the learning compulsion felt by students, besides that they find it difficult to adapt. with the distance learning system because so far they have lived in a faceto-face learning culture, and are accustomed to interacting directly. This rapid change in the learning system can also indirectly affect the learning absorption of students.

As for the $30 \%$ of respondents who want to continue learning online, they think that online learning is the only way to prevent crowds so that they can reduce the rate of new positive cases of COVID-19. Respondents who want to continue learning online think that online lectures make them flexible in terms of time. Meanwhile, $18 \%$ of respondents hoped that lectures would be conducted online interspersed face-to-face 2 to 3 times a month so that they would not be bored.

\section{CONCLUSION}

Student response is one of the requirements so that the learning process can run well so as to facilitate the achievement of maximum learning goals. The rapid and compelling change in the learning process from offline to online makes it important to understand the dynamics of diverse online learning.

The response of students from the biology department toward online learning generally stated that they were not happy. The displeasure and discomfort were caused by many things, including the difficulty of interacting directly with friends and lecturers, unstable internet connections and the cost of buying internet quotas is being higher. On the other hand, there is also a positive response from respondents who are happy because online learning makes them more flexible in terms of time. 


\section{RECOMMENDATION}

Responding to the results of this study, it is very important for lecturers and related policy makers to conduct a thorough evaluation of both the infrastructure, media and supporting learning methods so that the learning objectives can be achieved optimally.

\section{ACKNOWLEDGMENT}

This research received no specific grant from any funding agency in the public,commercial, or not-for-profit sectors.

\section{REFERENCES}

Andiarna, F \& Kusumawati, E. (2020). Pengaruh pembelajaran daring terhadap stres akademik mahasiswa selama pandemi covid-19. Jurnal Psikologi, Volume 16 Nomor 2, Desember 2020. DOI: http://dx.doi.org/10.24014/ jp.v14i2.9221

Arkorful, V., \& Abaidoo, N. (2014). The role of e-learning, the advantages and disadvantages of its adoption in higher education. International Journal of Education and Research, 2(12): 397-410.

Arnesi, N., \& Hamid, A.K. (2015). Penggunaan media pembelajaran online-offline dan komunikasi interpersonal terhadap hasil belajar bahasa inggris. Jurnal Teknologi Informasi dan Komunikasi dalam Pendidikan, 2(1): 85-99. https://doi.org/10.24114/jtikp.v2i1.3284

Astuti, C. C., Sari, H. M. K., \& Azizah, N. L., (2019). Perbandingan efektifitas proses pembelajaran menggunakan metode e-learning dan konvensional. Proceedings of the ICECRS, 2(1),: 35-40. http://doi.org/10.21070/picecrs.v2i1.2395

Dzalila, Lizha Q. A., Annisa A., Saifuddin Z. (2020). Pngaruh pembelajaran daring pada masa pandemi covid-19 terhadap tingkat pemahaman belajar mahasiswa. Jurnal Signal Volume 8, No. 2, Juli 2020, hlm 89-214. http://jurnal.ugj.ac.id/index.php/Signal

ECW. (2020). COVID-19 and education in emergencies. Diambil dari https://www.educationcannotwait.org/covid-19/

Fitriana, E., Utaya, S., \& Budijanto. (2016). Hubungan persepsi siswa tentang proses pembelajaran dengan hasil belajar geografi di homeschooling sekolah dolan kota malang. Jurnal Pendidikan: Teori, Penelitian dan Pengembangan, 1(4): 662-667. http://dx.doi.org/10.17977/jp.v1i4.6212

Haryadi, Rudi \& Idah Rosian. (2020). Pengaruh sistem pembelajaran daring terhadap motivasi dan kualitas belajar siswa. Jurnal Jurusan Bimbingan Konseling Undiksha Volume 11 Number 2, 2020, pp 136-141 ISSN: DOI: http://dx.doi.org/10.23887/jibk.v10i2 Open Access https://ejournal.undiksha.ac.id/index.php/JJBK/index

Isnayni, Mila Yatimatul \& Wildan Hermansyah. (2020). Pengaruh pembelajaran sistem daring terhadap mahasiswa tadris biologi dalam memahami materi mata kuliah biokimia. ALVEOLI: Jurnal Pendidikan Biologi Vol. 1, No. 1, Januari-Juni 2020.

Istiningsih, S., \& Hasbullah. (2015). Blended learning, trend strategi pembelajaran masa depan. Jurnal Elemen, 1(1): 49-56.

Kemdikbud. (2020). SE mendikbud: pelaksanaan kebijakan pendidikan dalam masa darurat penyebaran covid-19. Diambil dari https://jdih.kemdikbud.go.id/arsip/SE\%20Menteri\%20Nomor\% 204\%20Tahun\%202020\%20cap.pdf

Kemendikbud. (2021). Kemendikbud terbitkan pedoman penyelengaraan belajar dari rumah. Diambil dari https://www.kemdikbud.go.id/main/blog/2020/05/kemendikbudterbitkan-pedoman-penyelenggaraan-belajar-dari-rumah.

Kominfo. (2018). Pemerataan pembangunan infrastuktur telekomunikasi kawasan Indonesia timur segera terwujud. Diakses dari 
https://www.kominfo.go.id/content/detail/13279/pemerataan-pembangunaninfrastraktur-telekomunikasi-kawasan-indonesia-timur-segaraterwujud/0/sorotan_media

Komisi Perlindungan Anak Indonesia (KPAI). (2020). Ada 246 aduan di kpai soal belajar daring, siswa keluhkan tugas menumpuk-kuota. Diambil dari https://www.kpai.go.id/berita/ada-246-aduan-di-kpai-soal-belajar-daringsiswakeluhkan-tugas-menumpuk-kuota

Mashuri, H. (2017). Persepsi siswa terhadap pembalajaran guru pendidikan jasmani di sma muhammadiyah kediri. Jurnal Penelitian Pembelajaran Sportif, 3(1): 110. https://doi.org/10.29407/js_unpgri.v3i1.681

Muntazhimah., Eline Y. P. N., Sri Y. N. (2020). Respon siswa sekolah menengah terhadap pembelajaran matematika di era covid-19. Jurnal Pendidikan Matematika Vol. 8, No. 3, pp. $193-206$.

OECD. (2020). Supporting the continuation of teaching and learning during the COVID19 Pandemic. Diambil dari http://www.oecd.org/education/Supportingthecontinuation-of-teaching-and-learning-during-the-COVID-19-pandemic.pdf

Padli, Feri \& Rusdi. 2020. Respon siswa dalam pembelajaran online selama pandemi. Social Landscape Journal Pendidikan Ilmu Pengetahuan Sosial, FIS-UNM.

Purwanto, A., et al. (2020). Studi eksploratif dampak pandemi covid-19 terhadap proses pembelajaran online di sekolah dasar. EduPsyCouns: Journal of Education, Psychology and Counseling, 2(1): 1-12.

Rahman, S., Munawar, W., T. \& Berman, E. (2014). Pemanfaatan media pembelajaran berbasis website pada proses pembelajaran produktif di smk. Journal of Mechanical Engineering Education, 1(1): 137-145. https://doi.org/10.17509/jmee.v1i1.3746

Sa'diya, Nilam Puspah \& Brillian Rosy. (2021). Pengaruh pembelajaran daring terhadap hasil belajar pada masa pandemi covid-19. JIMEA| JurnalIlmiah MEA (Manajemen, Ekonomi, dan Akuntansi) Vol.5 No.2, 2021.

Sobron A.N. (2019). Persepsi siswa dalam studi pengaruh daring learning terhadap minat belajar ipa. Jurnal Pendidikan Islam dan Multikulturalisme, 1(2).

Sugiarto, et al. (2001). Teknik sampling, jakarta: PT. Gramedia Pustaka Utama.

Thahir, M., Roza, Y., \& Murni, A. (2018). Identifikasi persepsi dosen dan mahasiswa terhadap pembelajaran berbasis website (pbw) di prodi pendidikan matematika ftk uin suska riau. Jurnal Elemen, 4(2): 159-170. http://dx.doi.org/10.29408/jel.v4i2.709

UNESCO. (2020). Covid-19 educational disruption and response. Diambil dari https://en.unesco.org/covid19/educationresponse

Vonderwell, S., \& Savery, J. (2004). Online learning : student role and readiness. The Turkish Online Journal of Educational Technology, 3(3): 38-42.

Waryanto, N.H. (2006). Online learning sebagai salah satu inovasi pembelajaran. Jurnal Pythagoras, 2(1): 10-23.

Wardani, D. N., Toenlioe, A. J. E., \& Wedi, A. (2018). Daya tarik pembelajaran di era 21 dengan blended learning. Jurnal Kajian Teknologi Pendidikan, 1(1): 13-18.

Yunitasari, Ria \& Umi Hanifa. (2020). Pengaruh pembelajaran daring terhadap minat belajar siswa pada masa covid-19. Jurnal Ilmu Pendidikan Volume 2 Nomor 3 Tahun 2020 Halm 232 - 243 https://edukatif.org/index.php/edukatif/index 